\title{
Characterising marketing paradigms for sustainable marketing management
}

\author{
Hurth, V
}

http://hdl.handle.net/10026.1/10065

10.1362/204440817X15108539431541

Social Business

Westburn Publishers

All content in PEARL is protected by copyright law. Author manuscripts are made available in accordance with publisher policies. Please cite only the published version using the details provided on the item record or document. In the absence of an open licence (e.g. Creative Commons), permissions for further reuse of content should be sought from the publisher or author. 
Title: Characterising marketing paradigms for sustainable marketing management

\section{Authors names and affiliations:}

Dr Victoria Hurth, University of Plymouth

Bio:

Victoria is Associate Professor of Marketing and Sustainable Business at Plymouth University. She researches the concept of 'purpose-driven organisations' - a practitioner phenomenon focused on creating sustainable wellbeing through business success, and the role of marketing and governance in delivering this agenda. She has published research papers and thought pieces in journals including: Nature Climate Change, The New Scientist, Carbon Management and Sustainable Development. Victoria has over 15 years experience consulting in marketing and sustainability, having previously worked for Accenture with companies including Marks and Spencer, Cancer Research, J Sainsbury. She has been engaged by organisations such as The British Council, British Standards Institute, the ISO and LEAD International and is also active in local economic development. She co-convenes an ISO committee which is developing a proposed international standard in Governance of Organizations, and works with the $\mathrm{CMI}$ and $\mathrm{CIM}$ on progressing sustainable marketing and purpose. Victoria is a Chartered Marketer and Chartered Manager.

Dr Emma Whittlesea, University of Plymouth 
Bio:

Emma is a visiting Research Fellow in the Plymouth University Business School. Her professional and research focus has concentrated on community and industry transitions toward sustainability and climate resilience (adaptation and mitigation). She is an experienced and highly motivated sustainability and community development specialist, with experience gained working in government (local, regional and national level) and as a consultant, within the UK, Europe and Australia. Recent research includes examination of the challenges and opportunities for a low-carbon and climate resilient tourism economy in the South West of England, and a Green Economy project in the UK Overseas Territory of the Turks and Caicos Islands. Emma also coordinated the South West England representation on the 'European Research Network for Sustainable Tourism' (ERNEST), a four year project to share and develop research and development programs across 14 European Tourism regions.

\section{Corresponding author:}

Dr Victoria Hurth, Drake Circus, Plymouth, England. PL4 8AA (+44) 7706361085

\section{Acknowledgements:}

Victoria Hurth would like to thank Friends of the Earth, UK who funded previous research which this paper draws from as well as to Jules Peck, Enrico Wensing and David Jackman who contributed to that research. 
Title: Characterising marketing paradigms for sustainable marketing management

\begin{abstract}
Purpose: Economic theories shape marketing paradigms, and these, in turn, can either aid or inhibit marketing manager's ability to contribute to the goal of sustainability - long-term wellbeing for all. The marketing paradigm drawn on is therefore of great importance. Macro sustainable marketing literature does a good job of problematising the influence of neo-classical economic thinking over marketing, but translation and broader exploration of this problem, in a way that can be used in to positively transform marketing management at the meso level, is lacking. This paper's purpose is therefore to characterise three key marketing paradigms which draw from three economic theories of the firm - two of which are likely to hinder sustainable marketing and an emerging paradigm which is judged as compatible.
\end{abstract}

Design/methodology/approach: This is a conceptual paper which provides the basis for future empirical testing.

Findings: The three paradigms present highly variable approaches to why a firm exists, how wellbeing is viewed, the theory of the consumer, the dominant relationship focus and the dominant temporal outlook. Make-and-sell and senseand-respond, which are underpinned by classical and neo-classical thinking respectively, are likely to conflict with the goals of sustainability. Guide-and-cocreate, which is aligned to ecological economics, is compatible both to the delivery 
of sustainability but also to recent advances in marketing thought and practice. Six principles arise from these paradigmatic characterisations, which may form the basis of a maturity framework to guide marketing management and organisational change towards delivery of sustainability.

Limitations: As a wide range of disciplines and bodies of work are relevant to this paper, not all knowledge will be represented in the conceptual analysis of the problem and the proposed approach to address it. Empirical research is needed to test and further explore the 'guide and co-create' paradigm and the principles for a sustainable marketing maturity framework by marketing managers.

Implications: If marketing managers and their firms are to help deliver sustainability, they need be aware of their paradigmatic tendencies and those of their stakeholders at multiple-levels, and how they might help or hinder this. This paper highlights the tendencies that might exist and where these are unhelpful to driving sustainable marketing, to help marketers and managers deliver new ways of translating natural resources into high levels of wellbeing for all. This paper provides the foundation for system-wide understanding these tendencies and what paradigmatic shifts are required to advance genuinely sustainable marketing.

Contribution: The characterization of the three marketing paradigms set out in this paper, aid the exposure and debate of prevailing assumptions which shape marketing management and thereby is ability to deliver sustainability. In this way the paper contributes to bridging the gap between the critical marketing literature and the marketing management field. 
Keywords: sustainable, marketing, paradigm, purpose, sustainability, cocreation

\section{Introduction}

At a meta level, sustainability can be summarised as the achievement of long-term wellbeing for all (IUCN, 2006; Porritt: 2010), which by definition requires the sustainable use of resources. Marketing has long been critiqued for being a core driver of various unsustainable outcomes. Marketing has been blamed for hyperrisk (Beck, 1992), hyper-reality and related psychological issues (Baudrillard, 1998), a consumerist/materialist society and resulting unsustainable and unethical resource use (Domagalski \& Kasser, 2004; Crompton, Alexander \& Shrubsole, 2011). These criticisms have been echoed within the critical marketing discipline (e.g. McDonagh \& Prothero, 2014; Varey, 2010). At the same time, marketing's central role in helping achieve long-term wellbeing has also been widely noted (Carrigan \& de Pelsmacker, 2009; Fisk, 2001; Lim, 2016), with sustainable marketing representing a key concept as to how the positive aspects of marketing can be enhanced, and the negative aspects reduced (van Dam and Apeldoorn, 1996).

Achieving marketing behaviour that drives sustainability requires a dramatic shift in mainstream marketing management by those that implement, approve, support and deliberate marketing activities. This is true for organisational forms of all kinds within the private and public spheres and within multiple system levels and multiple types of actors (Caruana \& Chatzidakis, 2014). 
Despite the observed need for this shift, much of the critical sustainable marketing literature posits that it represents a huge if not insurmountable challenge. The reason for this is the intricate relationship between marketing thought and economic thought. A fundamental conflict is judged to exist between the goals of sustainability and the dominant neo-liberal economic paradigm which derives from neo-classical economic theory and features profit maximisation, short-term horizons and a rational view of human behaviour. The dominance of this economic approach at all system levels can inhibit marketing from addressing sustainability at the managerial level (e.g. Kilbourne, McDonagh \& Prothero, 1997, 2014; Schaefer \& Crane, 2005; Shultz \& Holbrook, 1999; van Dam \& Apeldoorn, 1996). A related concern is that critical marketing insights that are aligned to achieving sustainability may be diluted if they are applied in neo-classical managerial contexts (Wilkie \& Moore, 2012). These two aspects combined appear to have led to the relative lack of development of managerial approaches to genuinely sustainable marketing (Peterson, 2012). Of the examples that do exist, those widely referenced in standard marketing management texts do not make explicit the alternative paradigmatic base they draw on, or they fit frameworks of sustainable marketing into dominant economic thought (van Dam \& Apeldoorn, 1996; Saren, 2000).

The approach of reflecting dominant neo-classical perspectives when producing management texts may seem pragmatic. However, there are strong indications of 
an appetite to dilute the role of profit maximisation as the predominant reason for an organisation's existence - a core premise of the neo-classical theory of the firm. Instead, reflecting long-standing calls from marketing authors such as Kotler (Kotler, Kartajaya, \& Setiawan, 2010; Kotler \& Levy, 1969), societal wellbeing is being put forward as the primary concern of mainstream organisations' value creation by a range of private sector organisations, predominantly expressed under the term 'purpose' (Blueprint for Better Business, 2017; Ellsworth, 2012; Hollensbe, Wookey, Hickey, George \& Nichols, 2014; Laloux, 2014; Roderick, 2016; Sinek, 2009; Sisodia, Wolfe \& Sheth, 2003). Using the definition of sustainability as being about achieving long-term wellbeing for all, purpose can be interpreted as placing sustainability at the very heart of an organisation. The strong emergence of purpose as a pivotal organisations concept suggests that a narrow adherence to the edicts of a neo-classical perspective may be shifting at a foundational level.

Whilst some have sought to address the gap between the critical and managerial literature in the sustainable marketing field (Peterson, 2012; Belz \& Peattie, 2009; van Dam \& Apeldoorn, 1996; Lim, 2016; Gordon, Carrigan \& Hastings, 2011), there is, as yet, no simple representation of the core marketing world views and their implications for managing marketing's role in advancing sustainability. Summarising these marketing perspectives in a clear and comparable fashion, which exposes the role of economic thought, would expose the landscape and highlight the specific issues at hand. This would increase the chance their influence 
can be grasped, debated and understood by a range of stakeholders, including business and marketing schools, institutions and organisations. Additionally, it would further aid the development of research and marketing management which is cognisant of principles that are aligned to achieving sustainability.

Paradigms are conceptual world-views that consist of interconnected practices and ways of thinking which guide decision making. They therefore represent a foundational barrier (or opportunity) to implementing genuinely sustainable marketing. They are prone to persist at the doxic level of unquestioned truths, and hence require detailed attention in order to unlock change at multiple system levels. For example, strong levels of short-termism may exist within a paradigm and shape shareholder expectations. These then may manifest themselves within the organisational level incentive structures, which in turn structure daily marketing decisions. The effect of paradigms at different system levels need to be considered if marketing communications are to be enabled to consistently and effectively promote sustainability. Therefore, exposing all levels of the system to information about how marketing behaviour is structured by core paradigms, could support system change.

Hence, a need exists for a usable characterisation of core paradigms of marketing and how they are related to dominant economic belief. As such the aim of this paper is to outline what these usable characterisations might be. This conceptual paper will characterise three marketing paradigms that are significant for 
sustainable marketing management. Two dominant paradigms of marketing (make-and-sell and sense-and-respond), based on two distinct yet interconnected economic theories of the firm (classical and neo-classical) are introduced, followed by an emerging paradigm (guide-and-co-create). Each paradigm's compatibility with sustainable marketing is examined, concluding that the first two paradigms are incompatible and the third is aligned with marketing management that can deliver sustainability. In concluding, the key features of the guide-and-co-create paradigm are expressed as a set of principles. These are offered as a potential basis of a marketing management maturity framework by organisations, marketers and other stakeholders, at both the strategic and tactical level. In order to set the context and characterise the paradigms, it is necessary to draw on a wide range of literature from a variety of disciplines, including marketing (including sustainable marketing), economics, consumer culture theory and psychology.

\section{Sustainability and marketing}

Although definitions of sustainability have always been highly contested (McManus, 1996), it is frequently aligned with the goal of equitable long-term human wellbeing, which is viewed as encompassing the separate dimensions of environmental, social and economic sustainability. A focus on wellbeing is compatible with theories of sustainable development because wellbeing represents an overarching focal point that supports a whole systems approach (Giddings, Hopwood, \& O'Brien, 2002). Although there are those who take a deep ecology approach where the intrinsic value of nature is the core concern, most 
conversations about sustainability, even those environmental in nature, are about human wellbeing. By way of example, the IUCN (2006 p.12) quoting Paehlke (2005), says: "The relevant metric of sustainability is the production of human wellbeing per unit of extraction from or imposition upon nature". In a business context this focus is maintained. For example, the definition of a sustainable economy as used by HRH Prince of Wales' Cambridge Programme for Sustainable Leadership (Porritt: 2010, p.11), is one that: "achieves and maintains a high level of wellbeing for all people, now and in the future, that works within the constraints of nature". Following this, sustainability is understood here as the realisation and maintenance of high levels of wellbeing for all, which, by definition, implies the regenerative and ethical use of human and non-human resources. Wellbeing can be broadly seen as either hedonic or eudaimonic drawing from Epicurean or Aristotelian thought respectively (Ryan and Deci 2001). The eudaimonic approach is taken here and this equates to flourishing or the 'good life', which includes being able to participate purposefully (Brand-Correa and Steinberger, 2017) as opposed to hedonic which is interpreted as individualistic and pleasure orientated.

Marketing has been defined by the American Marketing Association in 2007 as the activity, set of institutions, and processes for creating, communicating, delivering, and exchanging offerings that have value for customers, clients, partners, and society at large. Marketing is recognised by many as being critical to addressing sustainability, and it is also recognised in many quarters as the core function which shapes a business (see Webster, 2009 for an overview of Drucker's influential 
views on this). At a functional level, marketing has a strong influence on sustainable resource use within the value chain through how products are designed, distributed and disposed of. More profoundly, marketing is also acknowledged as having significant impact on identities, culture and societal behaviour, and as a result could be described as the key player in match-making resources and human wellbeing through pathways of associative meaning. In this respect, authors have emphasised how marketing has an intricate relationship with societal functioning (Alderson \& Cox 1948; Wilkie \& Moore 1999, 2012; Varey, 2013; Laczniak \& Murphy, 2006). The influence of marketing on wellbeing, via its effects on the psycho-socio-cultural realm, has attracted attention for decades from outside the marketing field (e.g. Baudrillard, 1998; Beck, 1992; Douglas \& Isherwood, 1979). Key anthropological critiques relate to marketing's role in the development of materialism, commodification of our lives, reduction in happiness and psychological quality of life.

Much has also been written about key aspects that underpin marketing's ability to effectively contribute to long-term societal wellbeing. In the social domain this has been variously termed societal marketing (Kotler \& Levy, 1969), social marketing (Andreasen, 1994; Peattie \& Peattie, 2009), welfare marketing (Varey, 2010), quality of life marketing (Arndt, 1981; Kilbourne et al., 1997; Lee \& Sirgy, 2004; Sirgy, Meadow \& Samli, 1995) and ethical marketing (Laczniak \& Murphy, 1985, 2006; Martin, 1985). Others have dealt specifically with environmental aspects which either implicitly or explicitly impact societal wellbeing e.g. Ecological 
marketing (Fisk, 1974; Henion \& Kinnear, 1976), Green marketing (Peattie, 1999; Ottman, 1992), Greener marketing (Charter 1992), Eco-marketing (Fuller \& Bulter, 2014), Environmental marketing (Coddington, 1993) and Enviropreneurial marketing (Menon \& Menon, 1997). These deal predominantly with the organisational contribution to sustainable marketing practices, although the increasing role of consumers in advancing sustainable marketing is also recognised (Caruana \& Chatzidakis, 2014). Amongst this array of terms that consider marketing's contribution to sustainability is the concept of sustainable marketing where much of the relevant literature lies.

Sustainable marketing has been interpreted in a variety of ways by different authors. Sheth and Parvatiyar (1995) and Fuller (1999) focused mainly on environmental aspects. More recent conceptions of sustainable marketing have drawn from a holistic view of sustainability where the social, environmental and economic interconnect, as first made apparent by van Dam and Apeldoorn (1996). Building on these conceptualisations of sustainable marketing, connections are being more concertedly made between the concepts of sustainable marketing and sustainable wellbeing (Lee \& Sirgy, 2004; Varey, 2010, 2013). There is no one recognised definition of sustainable marketing, and this is arguably less important than the fact that it can serve as an umbrella term (Hirsch \& Levin, 1999) which aspires to align marketing thought and practice with the delivery of sustainable wellbeing for all. In this paper sustainable marketing is understood as "marketing within, and supportive of, sustainable economic development" (van Dam \& 
Apeldoorn 1996, p. 46), which in turn connects directly to the provision of longterm wellbeing for all.

\section{Calls for a new marketing paradigm}

A Kuhnian-based understanding of a paradigm (Kuhn, 1970) is a conceptual worldview that consists of interconnected practices and ways of thinking which guide decision making. Over time, the testing of these practices against reality throws up anomalies and problems that expose the inadequacies of the paradigm. Once the weight of this evidence is strong enough, a radical shift in paradigm, and therefore associated practices, frameworks and thinking, ensues. As well as drawing on this view of paradigms, we also draw on Kuhnian critics who point out that periods of time are not related to one specific paradigm but that competing paradigms have always co-existed in history (Feyerabend, 1970; Lakatos 1970,1977).

How sustainable marketing is conceived fundamentally depends on the paradigmatic assumptions it rests on. The theory of the firm represents the fundamental logics of thinking as translated at the level of the firm: why it exists in the first place (its purpose) and where and when value resides. Although it is often conceptualised at the macro level - i.e. why firms as a whole exist in society - at an organisational level it is akin to the dominant logic (Prahalad \& Bettis, 1986) or "standard enterprise logic" (Varey, 2013, p.354). In a well-functioning organisation, the theory it adopts should shape a firm's internal governance and management systems and provides a paradigmatic frame for all functions, including marketing 
management (Anderson, 1982). It therefore shapes aspects of decision making, such as the firms responsibility and approaches regarding societal wellbeing, the assumed behaviour of and relationships with stakeholders, and temporal and spatial decision-making frames. Different 'theories of the firm' - and supporting ontological and epistemological frameworks about 'how the world works' - are therefore significant in shaping decision-making at all levels of an organisation. A wide range of 'theories of the firm' now exist within a number of disciplines, however, the economic theory of the firm is judged to be dominant at both the firm and societal level.

A wide range of literature exposes the nature and role of the dominant neoclassical economic theory of the firm, and connected neo-liberal social paradigm, in shaping how sustainable marketing has been approached, particularly in the managerial realms (e.g. Kilbourne, McDonagh \& Prothero, 1997; McDonaugh \& Prothero, 2014; Peattie, 2007; Saren, 2000; Schaefer \& Crane, 2005; Shultz \& Holbrook, 1999; van Dam \& Apeldoorn, 1996). Hence "companies have an almost universal emphasis upon economic returns, with consumption as the root towards profit maximization" (McDonagh \& Prothero, 2014, p.1198). It is well understood that marketing's understanding of itself cannot be separated from underlying economic thinking (Anderson, 1982; Arndt, 1981; Bartels, 1976; Vargo \& Morgan, 2005; Varey, 2013): "Economic science provided the foundation for the emergence of marketing" (Vargo \& Morgan 2005, p.46). Although marketing has since developed into a distinct discipline, its relationship with economics is still highly 
significant, not least because the dominant social paradigm is structured by economic logic (Kilbourne, 2004). Economics is significant for organisations, but also for sustainability, because at its heart it is the "study of allocating the resources available to society in a way that maximises social well-being" (Goodland \& Ledec, 1987, p.20).

Although these theoretical critiques of marketing offer the possibility of progress, for this to be realised, managerial approaches and frameworks need to be developed which can support a shift from the status quo of marketing to be in line with sustainability (Peterson, 2012). Unsustainable consequences of marketing are ultimately a result of daily decisions being made by marketers or those that undertake marketing practice (Gummesson,1991). Therefore, although marketing has been charged with cynically driving consumerism and materialism, it is also likely that most unsustainable outcomes of marketing are made inadvertently as a result of how decisions are incentivised and framed by the underlying paradigms, and through a range of organisational actors, including marketers. A number of scholars judge the incompatibility between the dominant economic theory of the firm and the goals of sustainable marketing to require a new paradigm of marketing (e.g. McDonagh \& Prothero, 2014; Belz \& Peattie, 2009; Grönroos, 2007; Varey 2010) or a broadened one (Kotler \& Levy, 1969). For this reason, many argue that it will require a conscious shift in paradigmatic assumptions, through managerial approaches, for marketing to become a predominant force for sustainability. As Saren (2000, p.747) lucidly notes: "there is a clear sense that nothing short of a 
revolutionary reassessment of basic marketing ideas, techniques, orientation and practice is required to achieve the undeniably radical goal of sustainability".

\section{The critical / managerial divide}

The potential for such a shift to occur is limited, because whilst there is a rich body of critical sustainable marketing literature, residing mainly in the macromarketing approach to sustainable marketing, there is concurrently a recognised lack of managerial approaches to sustainable marketing: both in general, and more specifically, those which draw from the critical literature (Peterson, 2012) - a rarity that has been noted (Hunt, 2012). Gordon et al. (2011) comment that although there have been attempts to incorporate critical marketing into sustainable marketing management literature (e.g. Peterson, 2012, 2013; Belz \& Peattie, 2009; van Dam \& Apeldoorn, 1996; Lim, 2016; Gordon, Carrigan \& Hastings, 2011), "the impact upon marketing education and practice has been marginal. Innovative thinking and a strong agenda is required to ensure that sustainability is viewed as an alternative approach to marketing theory" (p.155). Addressing this, McDonaugh and Prothero (2014, p.1186) recently called for: "theoretical and managerial reflections which tackle broader systemic and institutional issues within the discipline (of sustainable marketing)".

One reason for the lack of managerial literature that reframes the assumptions of marketing through a new paradigmatic lens, may be that critical marketing has tended to be averse to self-identifying as managerially focused: "if the content of 
a paper had managerial relevance, then it wasn't macromarketing." (Peterson, 2012, p.393). As well as reflecting problems of connecting different systems levels of analysis (Cavagnaro and Curiel, 2012), Wilkie and Moore (2012, p.63) elucidate a further reason for this disconnect when they express concern that overly managerial approaches can mean that an “organization's goals are being adopted by marketing thinkers without any external appraisal whatsoever." To avoid associated risks, they argue for a managerial approach to be taken only 'as appropriate' by marketing scholars. The assumption appearing to be that marketing management and unthinking acceptance of the dominant neo-liberal paradigm are unavoidably interconnected.

Hence, at the heart of the separation between sustainable marketing thought and managerial approaches, seems to be the recognised gulf between the appropriate paradigmatic logics of sustainable marketing and the existing paradigmatic logics of marketing - which is judged to rest on the dominant economic paradigm (Kilbourne et al., 1997; Kilbourne, 2004). As a result, some authors have gone as far as to question if sustainability can ever be made real within the current worldviews of managerial marketing (Peattie, 2007; Saren, 2000; van Dam \& Apeldoorn, 1996; Varey, 2010). Hence, it seems possible that fears of the incompatibility of marketing for sustainable societal wellbeing with the dominant paradigm of marketing practice may have led to a conceptual separation of the two realms. This may underpin the recognition that "both marketing researchers and 
practitioners struggle to understand how the principles of sustainability can be integrated successfully into marketing practice" (Lim 2015, p.233).

Whilst scarce in sustainable marketing scholarship, a managerial approach, on the other hand, dominates general marketing scholarship (Wilkie \& Moore, 2012; McDonagh \& Prothero, 2014). The risk with an approach that separates the critical from the managerial is that this risks leaving managerial approaches devoid of paradigmatic analysis, and therefore more likely to defer to implicitly held world views. Van Dam and Apeldoorn note (1996, p.50): "observations on how marketing could contribute to reaching sustainability tend to start by taking the present situation for granted and then continue with a discussion of the better products, better distribution, and better consumption styles that marketing could deliver". Such a minor tweaking of the current paradigm will necessarily fall short of the major changes in perspective sustainable marketing authors have argued for.

Marketing text books are a key way in which notions of sustainable marketing are transferred to the next generation of marketing managers. Definitions and frameworks of sustainable marketing used by this body of literature, implicitly or explicitly, tend to defer to (or not challenge), the dominant neo-classical logics of firm (profit maximisation for shareholders) and human behaviour (rational exchange) that dominate marketing management (Brownlie \& Saren, 1992; van Dam \& Apeldoorn, 1996; Varey 2010; Peattie \& Peattie, 2009; Lim, 2016). This was explicitly noted in the book review of Fuller's (1999) 'Sustainable Marketing' 
where Saren $(2000, p .5)$ summarises much of the issue at hand, both in terms of how managerial approaches reflect the dominant paradigm, but also how the managerial is juxtaposed with ideological progression: "the problems with the marketing concept are essentially ideological. Fuller appears to think that they are essentially managerial. Managers can "bolt on", as it were, a "green extension" to the basic concept and the traditional 4Ps approach to marketing and there you have it, Sustainable Marketing!'.

Additionally, the managerial dominance is reflected in leading journals. This is judged likely to be reducing the general exposure of sustainable marketing (McDonagh \& Prothero, 2014) and creating a fragmented data driven approach to the issue (Webster, 2009).

\section{Characterising paradigms to bridge the divide}

The issue of separation cannot be addressed by avoiding the managerial realm, or implicit agreement with a dominant logic that is inappropriate to achieving sustainability. It is argued here that advancing beyond this situation would be aided by clear and consistent declarations of the "present situation" (van Dam \& Apeldoorn, 1996), what the "organization's goals" are (Wilkie \& Moore 2012, p.63), and what constitutes the features of the "classic economic paradigm" (Lim, 2016, p.242), that marketing management frameworks and tools aimed at achieving sustainability may be drawing from. This is vital if alternatives are to be developed 
and communicated within organisations and discussions are to move from the critical to the practical.

There is a risk that any attempts to address the theory of underlying paradigms within the managerial level may be rejected by practitioners (van Dam and Apeldoorn, 1996). However, as some have argued, there appears little alternative but to confront this directly (Gordon et al., 2011), at least in combination with providing support and influence at the regulatory and political level (van Dam \& Apeldoorn, 1996). Therefore. although the task will require a range of system level interventions, concerted effort is also needed to raise implicit paradigmatic assumptions that are held at a managerial level away from the underlying doxa up to the conscious level of discursive elaboration (Bourdieu, 1977) where they can be debated and reformed. Without this, sustainable marketing frameworks may clash unwittingly with the dominant logics - thereby providing dissonance without resolution for marketing practitioners. This also stunts progress in developing frameworks that progress sustainable marketing that is fit for purpose.

To address this multidimensional task, some frameworks of sustainable marketing have sought to separate the different theoretical lenses through which sustainable marketing might be understood - each one resting on a specific world view (Lim, 2016; Gordon et al., 2011). This paper takes an alternative approach by way of contribution, and instead characterises the key paradigms of marketing that underpin multiple contexts. The aim is to provide a clear, comparable and therefore 
usable representation of relatively stable paradigmatic alternatives that marketing managers and scholars are likely to face. In turn, these may help isolate the thinking and behaviours as they relate to each paradigm and therefore the implications for sustainable marketing. Further, these may provide a meme, or idea, that can be transferred, critically discussed and incorporated into sustainable marketing management frameworks by both scholars and, crucially, marketing managers and their firms.

When isolating paradigms, it is important to draw on existing paradigmatic change. There is visible change occurring within the marketing discipline, connected to an overall shift in business (Gummesson, 2002; McDonagh \& Prothero, 2014) which may provide the conditions for sustainable marketing to emerge. Disconnection from this evidence risks exacerbating the divide between marketing and sustainable marketing (Peattie, 2007; van Dam \& Apeldoorn 1996). Additionally, an appropriate sustainable marketing paradigm cannot be completely idealistically disassociated from current realities if it is to evoke change (Aitken, Ballantyne, Osborne \& Williams, 2006; Kilbourne, 2004; Lim, 2016; Peattie \& Peattie, 2003).

Although it is recognised that a range of approaches to identifying paradigms exist, this paper argues the economic theory of the firm offers a useful starting point to isolate a small number of relevant paradigms. This is because economic thinking is fundamentally influential for marketing, sustainability and the dominant social paradigm (Dunlap \& Van Liere, 1984; Kilbourne, 2004). 
The paper will proceed by outlining two dominant marketing paradigms: make-andsell, which is aligned to classical economic thinking, and sense-and-respond, which is aligned to neo-classical economic thinking (which is related to neo-liberal ideology). Their relationship with marketing paradigms and their incompatibility with sustainable marketing will be discussed. We then summarise an emerging marketing paradigm that we term 'guide-and-co-create', and argue that this is aligned to an emerging theory of the firm that is compatible with delivering sustainability - realising long-term wellbeing for all. In outlining the paradigms, a range of literature from outside the marketing realm will be drawn on.

\section{Paradigm 1: Make-and-Sell}

A 'make-and-sell' view of marketing and the firm is 'enterprise-centric'. The company's role is to efficiently plan, make and then sell offerings (Keith, 1960; Haeckel, 1999, 2010). This paradigm represents a firm-stakeholder relationship that starts internally with the firm and resonates outwards. Here marketing is an 'end of pipe' function where its main purpose is sales and promotion. Within this paradigm, marketing's temporal focus tends to be short-term - the purpose of the business is near-term sales and profits (Haeckel, 1999, 2010). The make-and-sell paradigm could be seen as aligned to the classical economic theory of the firm. Within later classical economic thought, the focus is on near-term internal costs and their relation to market price: growth is the core focus of concern and this is seen as contingent on the cost of production, hence value lies in reduction of price, 
via costs (Antonio, 2015; Smith, 1776; Vaish, 2009). Further, the focus on production derives from the notion that supply (and the income generated from it) will feed its own demand (Say, 1834). This gives rise to an internal productionfocused approach, both to organisational activities and the judgement of performance (Christensen, 1989).

Although, mirroring classical economic theory of the time, make-and-sell has been assessed as being dominant in a specific historical phase (Haeckel, 2010; Keith, 1960; LaLonde, 1963). The indications from these assessments are that first, there is a common view that Western business was at one point in history (sometime between the late $19^{\text {th }}$ Century and mid $20^{\text {th }}$ ) dominated by a make-and-sell philosophy - around the same time that classical economics prevailed in organisations. Second, that it is not just history that can be seen to determine the phase but also an organisation's individual journey towards maturity (Schutte \& Wind, 1968). Therefore, despite the rhetoric of many marketing textbooks that situates 'make-and-sell' as a historic artefact, it is perhaps more accurate to consider it an indicator of corporate maturity. This is supported by assessments that many companies could be considered 'stuck' in a make-and-sell paradigm (Haeckel, 1999, 2010) and indications from editors of leading journals, that marketing may only just be at the beginning of a shift from a product-centric and peripheral role (Kumar, 2015). 
Haeckel (2010) attributes the persistence of the make-and-sell approach to the inherent stubbornness of tacit logics that constitute a paradigm. Because the make-and-sell paradigm sits within the "efficiency-centric industrial age managerial frame that assumes gradual and incremental change", inertia to change from this paradigm is compounded (Haeckel, 2010, p.27). Certainly there is evidence that the paradigm did not cease at a particular moment in time. One clear example of this is the acclaim, and continuing relevance, placed on Levitt's 1960 article, Marketing Myopia, which explicitly focused on the dangers of a firm being 'productfocused' (Levitt, 1960). In other words, if the scope of the company is defined narrowly (e.g. railroads instead of transportation or indeed participation and subsistence) and the inspiration for innovation and measures of success are internally focused, a blinkered business model and associated decision making ensues, which is distanced from the lives of customers.

Within this paradigm, wellbeing has been equated to financial wealth accumulation (Smith, 1776), but also to the concept of welfare (Pigou, 2013) which meant that it was not just about accumulating wealth but also about its stability and distribution (Aslanbeigui \& Oakes, in Pigou, 2013). Classical economist, Pigou also brought forward the concept of negative externalities that might affect a large majority of society as a result of an institutionalised system of self-interest (Nordhaus, 2011). However, economists like Pigou believed that it was economic policy, not economic science, which should deal with human philosophical issues such as the nature of wellbeing. Therefore, welfare and wellbeing should not be conflated 
(Aslanbeigui \& Oakes, in Pigou, 2013). It is perhaps these kinds of deliberations, along with significant issues of measurability, which gave rise to wellbeing being seen as out of scope for economics.

Smith's detailed motivational observations in his Theory of Moral Sentiments (1790, [2010]) perhaps characterised much of the theory of the consumer of classical economics. He noted that people's behaviour, whilst partly driven by selfish tendencies (which often produce outcomes in the public interest), are determined in large part by the will to attain self-respect and the respect and praise of others. This respect is predicated on honourable, empathetic and moral actions. He also believed that people's behaviour must be understood in a social context.

\section{Paradigm 2: Sense-and-Respond}

The second major paradigm of marketing, which guides current normative notions of best practice marketing, arrived with the dawn of the 'marketing concept', and directly succeeded the make-and-sell era (Haeckel, 1999; LaLonde, 1963; Schutte \& Wind, 1968). As is widely known, this became the "cornerstone of contemporary marketing philosophy” (Elliott, 1990, p.20). From the marketing concept emerged marketing orientation (a focus on customers) and market orientation (a focus on customers and competition) (Gray, Matear, Boshoff \& Matheson,1998; Jaworski \& Kohli, 1993). This shift marks at least a theoretical transition in the role of marketing from connecting pre-existing offers to markets, to marketing as the strategy setter. It placed customers as a primary stakeholder and creating value for them was the 
focus of tactical and strategic efforts to ensure profitability. Consequently, for a company with a marketing orientation, marketing thought and practice became central to determining a company's business model and success.

The dominant paradigm that has emerged from the marketing concept can be described as 'sense-and-respond' (Haeckel, 1999; Jayachandran, Hewitt \& Kaufman 2004) - continually monitoring customer demands and then shaping the business to deliver against them. It is otherwise termed as "customer-back versus firm-forward' (Haeckel 1999, p.229). Those companies adopting a sense-andrespond approach "continuously discover what each customer needs, sometimes even anticipating unspecified needs, and then quickly fulfilling those needs with customized products and services delivered with heretofore unavailable capabilities and speed" (Bradley \& Nolan 1998, p.4).

For Haeckel (1999) this paradigm is about quick adaptation to changes in customer requirements but also about a fundamental change in business purpose - from maximising shareholder value to maximising customer value. We argue this shift in the overarching business goal suggests change that ought to have occurred to align with the marketing concept, whereas evidence suggests that such a radical overhaul of fundamental business purpose has not happened. Instead the shift that actually happened represents a change in the economic theory of the firm - a movement in economic thinking from classical to neo-classical, via what is otherwise known as the marginal revolution (Antonio, 2015). In fact, this shift in 
economic thinking occurred alongside an even greater focus on the overarching goal of short-term profit maximisation for shareholders (Stockhammer, 2004). Through the marginal revolution, price determination of an offering moved from a focus on production costs to its perceived value, or marginal utility, by customers. This marginal utility became the proxy for wellbeing. Everyday decisions of consumers were situated as the dictator of firm behaviour (Persky, 1993), encompassed clearly in the associated concept of Consumer Sovereignty (Hutt, 1940).

Through the neo-classical view, the firm is tasked with providing for society's needs through reading and responding to revealed preferences in the market (Samuelson, 1948) - mirroring the marketing concept. The theory of the consumer within this view is that individuals are self-interested rational beings, or boundedrational decision makers (Simon, 1982) who, with the right information, can maximise their welfare through decisions they make from alternatives offered in the marketplace (McFadden, 2006; Sen, 1977). Although different theories of the consumer exist concurrently, the dominance of the 'rational human' view can be observed in marketing thought within mainstream academia and practice, and is also evident in the realm of sustainable marketing (Schaefer and Crane, 2005).

Significantly, the role of the firm is not to influence, or even concern itself with what people demand (from a libertarian viewpoint this would be a paternalistic distortion of the market), but merely to understand the market requirements and then deliver 
them. Through this lens "people's needs - for company, children, food, technology, travel and trinkets - are private affairs; control, if possible at all, is impermissible" (Wissenburg, 1998, p.212).

In this context, sense-and-respond marketing is arm's length, short-term focused and driven solely by current demands of customers, or possible anticipation of what they might want next. This directly relates to the heart of the contemporary marketing paradigm, as Brownlie and Saren (1992, p.40) summarise: "it is a basic tenant of marketing ideology that firms should satisfy consumer demand - and that such demand is itself determined by the choice and expression by consumers of their needs and wants". The conflict that this poses for marketers who understand the constraints and paradox of such a narrow view of innovation is often remarked on by practitioners and academics (Brownlie \& Saren, 1992). Hence, it is widely understood that marketing has a profound influence over society and in reality sets out to deliberately influence preferences (Jameson, 1991, Crompton \& Kasser, 2009). However, revealed norms suggest that this deliberate influencing of customers is not something that sits easily within a sense-and-respond paradigm of marketing - arguably due to its fundamental alignment to socially dominant neoclassical economic thinking, which 'prohibits' this. Although usually tacit, the underlying conflict is occasionally revealed, for example, when Rory Sutherland (then President of the Institute of Practitioners in Advertising) felt the need to specifically address the industry norm of denying influence over society suggesting that if you do not believe that society can be influenced at a sub- 
conscious level then you must be an ineffective marketer (Sutherland, 2010; Crompton et al., 2011).

Protecting the autonomy of rational individual preferences and the arms-length relationship with consumers, is reflected in the reticence to engage in choiceediting as a sustainable marketing approach (Hobson, 2004). Marketing hence focuses its energy on monitoring revealed preferences, for example through heavy reliance on market research, but without overtly setting out to deliberately lead them - what could be called 'read not lead'. Reflecting the economic underpinning, a focus of this market research might be what the marginal value of a one-unit improvement of a desired attribute of a product is (Hayes \& Abernathy, 1980; Haeckel, 1999).

On the one hand 'make-and-sell' and 'sense-and-respond' could be seen as polar opposites in terms of their initial relational and innovation focus - make-and-sell being the internal desire for cost reduction and increased sales, and sense-andrespond being external scanning of customer insights to drive sales through nearterm customer satisfaction. However, what they share at their core is a short-term, profit-focused relationship with customers that derives from both the classic and neo-classical theories (Vaish, 2009). Within both paradigms, markets tend to be analysed over a short time horizon with the long-term being marginalised (e.g. Anderson, 1982; Clark, 1907; Eatwell, 1987; Marshall, 1890). This results in opportunism to respond to near term variations, for example a change in sales 
tactics (make-and-sell) or through rapid innovation to adapt to a short-term consumer preference (sense-and-respond). Although make-and-sell does not meet the goal of consumer sovereignty, it does not contravene the space between customer as preference setter and firm as the provider. This has significant implications for the ability for both paradigms to enable sustainable marketing and this will now be explored through analysis of the emerging 'guide-and-co-create' paradigm. The similarities and differences between the make-and-sell and senseand-respond paradigms are represented in Table I: 
Table I. Comparison of the Make-and-Sell and Sense-and-Respond Paradigms of Marketing

\begin{tabular}{|c|c|c|c|}
\hline \multicolumn{2}{|c|}{ Marketing paradigm: } & Make-and-Sell & Sense-and-Respond \\
\hline \multicolumn{2}{|c|}{ Theory of the firm: } & $\begin{array}{l}\text { Purpose: Profit } \\
\text { maximisation for } \\
\text { shareholders. } \\
\text { Value: via cost of } \\
\text { production } \\
\text { Focus: Internal } \\
\text { Dominant economic } \\
\text { theory: Classical } \\
\end{array}$ & $\begin{array}{l}\text { Purpose: Profit maximisation } \\
\text { for shareholders. } \\
\text { Value: via consumer } \\
\text { preference } \\
\text { Focus: External } \\
\text { Dominant economic } \\
\text { theory: Neo-classical }\end{array}$ \\
\hline \multirow{4}{*}{$\begin{array}{l}\text { Paradigmatic } \\
\text { aspect: }\end{array}$} & $\begin{array}{l}\text { 1. Approach } \\
\text { to wellbeing }\end{array}$ & $\begin{array}{l}\text { Wellbeing is not the } \\
\text { concern of economics. } \\
\text { Welfare is considered } \\
\text { through recognition of } \\
\text { some intervention to } \\
\text { reduce externalities }\end{array}$ & $\begin{array}{l}\text { Utility is a proxy for wellbeing } \\
\text { which was determined by } \\
\text { rational consumers as } \\
\text { responded to by firms }\end{array}$ \\
\hline & $\begin{array}{l}\text { 2. Theory of } \\
\text { the } \\
\text { consumer }\end{array}$ & $\begin{array}{l}\text { Humans can be selfish } \\
\text { but this is held in check } \\
\text { by an inherent desire } \\
\text { for self-respect and } \\
\text { respect from others. } \\
\text { Behaviour must be } \\
\text { understood in a social } \\
\text { context }\end{array}$ & $\begin{array}{l}\text { Humans are self-interested } \\
\text { rational beings, or bounded- } \\
\text { rational decision makers } \\
\text { who, with the right } \\
\text { information, can maximise } \\
\text { their welfare through } \\
\text { decisions they make from } \\
\text { alternatives offered in the } \\
\text { marketplace }\end{array}$ \\
\hline & $\begin{array}{l}\text { 3. Dominant } \\
\text { relationship } \\
\text { focus }\end{array}$ & $\begin{array}{l}\text { Internal } \\
\text { (sales) }\end{array}$ & $\begin{array}{l}\text { External } \\
\text { (response) }\end{array}$ \\
\hline & $\begin{array}{l}\text { 4. Dominant } \\
\text { temporal } \\
\text { outlook }\end{array}$ & \multicolumn{2}{|c|}{$\begin{array}{c}\text { Narrow (firm and market system), fragmented, linear, } \\
\text { short-term }\end{array}$} \\
\hline
\end{tabular}




\section{Paradigm 3: Guide-and-Co-create}

Although still undeniably dominant, neo-classical economic orthodoxy has suffered seismic interconnected blows to its premise, and position. These include rationality (Kahneman, Slovic \& Tversky, 1982), the inability to reduce poverty (Stiglitz, 2010), and the failings that the economic crash of 2008 highlighted which has prompted whole scale national reviews of the role of key organisations in society (Kay, 2013). As well as direct attacks, neo-classical economics is a noted example of modernist thinking - expressing hierarchical structures, meta-narratives, correct scientific methods and statements, and assuming rational objective decision-making (Ruccio \& Amariglio, 2015). Challenges to modernist thinking via postmodernism (Featherstone, 1991), pragmatism and more recently post-postmodernism (Hickman, 2007), have served to simultaneously highlight issues with neo-classical economic thought and offer alternative conceptualisations of varying degrees of practicality. Drawing from the above, two key areas of challenge that underpin an emerging paradigm of marketing could be summarised as: 1) where the focus of value creation lies (the theory of the firm) and 2) the theory of the consumer. These challenges underpin a fundamentally changed relationship between the firm and society and as such could be summarised as a new paradigm which we call 'guideand-co-create' for sustainable wellbeing. Here 'sustainable wellbeing' becomes the central concept of the economic theory of the firm, and guide-and-co-create is the paradigm of marketing that supports it. This assertion is positive in that the paradigm can be observed as one that is emerging and normative to the extent that we are suggesting that it is a necessary condition of sustainable marketing. 
Changes to the theory of the firm

New approaches to marketing theory have helped move beyond neo-classical economic thinking regarding where the focus of value creation lies, and therefore a firm's reason for existence. For example, the marketing orientation concept has been expanded by a number of authors away from a narrow focus on customers as the source of value, to include a systemic focus on all external stakeholders and their interdependencies (Lusch \& Laczniak, 1987; Hart, 1995; Wheeler, Colbert \& Freeman, 2003). Additionally, Hunt's Resource Advantage Theory (RA Theory) (1997) and Vargo and Lusch's Service Dominant Logic (2004), have been prominent in moving from a narrow conception of value to a more systems-based perspective where value is situated and created by a range of system stakeholders. However, these do ground value in wellbeing, or go so far as to suggest reconsideration of profit maximization as the overarching purpose of the firm. For example, Hunt (2011) when specifically addressing RA theory and sustainable marketing argues that the organisational threats posed by natural and social issues can be addressed by pursuing superior financial performance as the primary goal. Money can then be made that can be invested into green initiatives such as contributing to sustainability causes. Here, Hunt depicts the alternative of 'for profit' to be a financially unsustainable company and does not seem to entertain the idea that social purpose might lead to superior long-term performance. Amongst other limitations, this places sustainability as something a firm uses its profits to invest in, rather than long-term (sustainable) profitability 
being the goal. Hence this appears to support a narrow view of Corporate Social Responsibility rather than more expansive thinking on shared value (Porter \& Kramer, 2011) or 'purpose' (Hollensbe et al., 2014). RA theory therefore does not appear presently to offer a firm level logic which allows for sustainable marketing's direct role in delivering long-term societal wellbeing.

In contrast, the emerging theory of the firm puts the concept of wellbeing as a specific and central topic of discussion. Therefore, contrary to make-and-sell and sense-and-respond, it is not assumed that subjective preferences of need satisfaction are revealed through consumption behaviour and traditional marketing research (Mick, Pettigrew \& Ozanne, 2012). Representing the systemic view of sustainability used in this paper, a range of pluralist economic perspectives support the idea that economics should be reformulated as being about the production of sustainable wellbeing (Costanza, Alperovitz, Daly, Farley, Franco, Jackson, Kubiszewski, Schor \& Victor, 2013; McGregor \& Pouw, 2016; UNESA, 2012). This thinking has entered related domains such as entrepreneurship (Parrish, 2010) and sustainable marketing (Lee \& Sirgy, 2004; Varey, 2010, 2013). It is also at the heart of the mainstream phenomenon of 'purpose-driven' business. This represents a movement in the focal units of analysis for a firm, from intermediate means (money (profit), goods and services) which create intermediate ends (income, jobs, skills), to a focus on ultimate means (human and environmental capital) in order to achieve ultimate ends (wellbeing) (Daly, 1971). There are significant implications for marketing that arise from situating wellbeing as a 
concept that must be defined and managed rather than assumed, something which has been variously explored within the marketing and sustainable marketing literature (Arndt, 1981; Kilbourne et al., 1997; Kotler \& Levy, 1969; Lee \& Sirgy, 2004; Sirgy et al., 1995; Varey, 2010).

Rather than being able to distance itself from unintended consequences of marketing activities on wellbeing, marketing instead must address these wellbeing system effects as the marker of success or failure. This helps bring into the mainstream marketing management realm, the core contention that marketing creates perverse associations between goods and human wellbeing and instead focuses on the proliferations of wants, which may or often do not, actually improve wellbeing (Max-Neef, 1991; Baudrillard, 1998). Furthermore, the measures of success and timescales over which success is judged are changed. Social impact metrics are becoming increasingly important in central reporting and governance within business that are becoming purpose-driven. Therefore, the work on metrics related to the quality of life marketing field (Sirgy, Michalos, Ferriss, Easterlin, Patrick \& Pivot, 2006), are central for developing marketing metrics regarding wellbeing.

Perhaps one of the reasons neo-classical economics has been so widely embraced is it helpfully removes the requirement for philosophical debate about the nature of valorised action. In contrast, a sustainable wellbeing focused theory of the firm necessitates direct engagement with the controversial topic of needs, 
as the core means by which wellbeing is attained as the ultimate human goal (Arndt, 1981; Brand-Correa \& Steinberger, 2017; Jackson, 2005). Needs are also central to the concept of sustainability (Bruntland, 1987) and marketing (Arndt, 1981), making them a crucial concept in unlocking sustainable marketing. The contributions by marketing scholars have done much to advance a burgeoning literature concerned with the classification and attainment of needs and contingent wellbeing (e.g. Sirgy et al. 2006), building on prominent work in the development field by authors such as Nussbaum and Sen (1993) and the economist Max-Neef (1999). However, there remain a number of barriers to conceptualising how sustainable marketing can contribute to sustainable wellbeing. Firstly, there are a wide range of concepts that are sometimes used interchangeably (e.g. wellbeing, quality of life, flourishing, thriving, welfare, value, capabilities, satisfaction, happiness, needs) but at closer inspection are not the same thing. The proliferation of marketing approaches that reflect these different concepts but do not often draw clear lines between them, provide a barrier to integration of this work into sustainable marketing practice. A key clarification required is the relationship between the central concepts of needs and value - which are also sometimes equated (e.g. Grönroos, 2000). Needs are often defined as objective inventories applicable to all humans which are subjectively met through systems of wants but value is more closely conceived as only subjective to the individual - thereby compatible with the neo-classical paradigm. 
A second barrier is that currently only a limited explication of which perspective of needs is taken - marketing text books have tended to rely on cursory reference to Maslow's hierarchy (Arndt, 1981). When considering needs, is vital that the adopted 'theory of the consumer' is exposed, because this will shape how needs are understood and how in turn they connect to value and wellbeing. For example, some have noted the usefulness of economist Max-Neef's approach to needs and their satisfaction (e.g. Jackson and Marks, 1999). Max-Neef posits a suite of needs that are all required to be met concurrently in order for human wellbeing to be optimised and therefore 'flourishing' to occur. Significantly he notes how although these needs are universal, the ways in which they are delivered through modes of satisfaction (e.g. personal motorised vehicle) or particular economic goods (e.g. a Ford $4 \times 4$ ) is entirely dependent on the particular socio-cultural context. Hence this highlights how systems of meaning association (which marketing is central to) are important gatekeepers to both levels of wellbeing and how sustainable the use of resource use is in order to deliver it. Max-Neef's approach is supported here as particularly useful because it is aligned with a Consumer Culture Theory (Arnould \& Thompson 2005) view of society - which is core to the emerging paradigm of guide-and-co-create. It is also aligned with a eudiamonic view of wellbeing as it based on understanding the broad remit of human flourishing. On the other hand, Maslow's hierarchy implies a rational choice which guides fulfilment of needs in a linear order and could be seen as aligned with a hedonic view of wellbeing (BrandCorrea \& Steinberger, 2017). 
Changes to the theory of the consumer

The second wave of challenge to neo-classical economic thinking is situated in the theory of the consumer. This is where the incompatibility of the make-and-sell and sense-and-respond paradigms for sustainable marketing becomes further elaborated. Emerging perspectives on the theory of the consumer give rise to two key aspects of the 'guide-and-co-create' paradigm - first, the recognition of unavoidable marketing leadership (guide), and second, co-creation as the viable route to sustainable wellbeing and value creation (co-create).

\section{Marketing as societal leadership}

There has been a raft of well-documented attacks on the notion of 'rational man' from the fields of psychology and from within economics itself. Kahneman and colleagues' work (Kahneman et al., 1982) has famously spurred the field of behavioural economics where the biases that undermine rationality are specifically considered in a way to which economics can adapt. However, there is also a prolific body of evidence, now generally summarised under the umbrella of Consumer Culture Theory (CCT) (Arnould \& Thompson 2005), from within the field of sociology and anthropology that outlines the more complex ways human decision-making occurs and changes, as well as the changing, multi-level contexts in which they are occurring (e.g. Blumer, 1969; Csikszentmihalyi \& RochbergHalton, 1981; Shove \& Pantzar, 2005; Wilk 1999, 2002). Within the emerging systemic 'sustainable wellbeing' theory of the firm, these alternative ways of looking at human behaviour become central, as some have noted (Kadirov \& 
Varey, 2011; Hurth, 2010). Specifically, with this view of human behaviour, the very idea that marketing management can avoid influencing society and culture at the macro level, and through the individual level, becomes untenable. This has been widely recognised in macro and critical marketing literature (e.g. Wilkie \& Moore, 1999; Firat, Dholakia \& Venkatesh, 1995) but far less so in mainstream marketing management literature.

Postmodern thinking (which here is used to encompass more recent pragmatic shifts to post-postmodernism) has emphasised the role of the symbolic in transmitting meaning. This exposes the dialectic relationship between all actors in shaping these symbols and constructing landscapes of meaning, which in turn shape the very essence of how we see the world, ourselves, and as a result what we value (Blumer, 1969; Jameson, 1991; Featherstone, 1991). Actors at all system levels, including customers, are therefore significant in driving consumption meaning and practices (Caruana, \& Chatzidakis, 2014). Marketing, as a mesolevel actor focused on symbolic meaning creation with very large budgets, is central to societal meaning creation. Marketing shapes society through individual behaviours it normalizes and valorises (Peñaloza \& Venkatesh, 2006; Rettie, Burchell, \& Riley,2012; Schaefer \& Crane, 2005; Lacznaik \& Murphy, 2006) and the social practices it helps mould (Shove \& Pantzar, 2005). Furthermore, with a postmodern focus on identities, the role of marketing in changing our sense of self and therefore what we do, has also been demonstrated (Elliott \& Wattanasuwan, 1998; Firat et al., 1995; Hurth, 2010; Oyserman, 2009), heightened by the shift to 
consumption rather than occupation becoming the dominant source of our identity (Bauman, 1998; Baudrillard, 1998; Featherstone, 1991; Jameson, 1991).

In terms of needs, the role of marketing in the psycho-social-cultural landscape means that marketing creates human and financial value by generating and reinforcing symbolic connections between needs, systems of needs satisfaction and particular economic offerings. It is this constructivist perspective that leads to the conclusion that: "Marketing can no longer pretend to be an instrumental discipline that affects consumers and society but has to become reflexive and has to be studied as the sociocultural process that defines postmodern society" (Firat et al., 1995, p.53).

However, within a make-and-sell or sense-and-respond paradigm of marketing, this way of consciously viewing the role of marketing is untenable. Even though it makes intuitive sense that marketing shapes individuals and society, and this knowledge can be observed to shape the decisions of marketers at all organisational levels, the idea of purposefully setting out to shape stakeholder's fundamental conception of value is diametrically opposed to the notion of a freemarket economy and idea of rational humans. In conflict with this, sustainable marketing rests on the active adjustment of customers' value perception and behaviour - 'marketing sustainability' (Martin \& Schouten, 2012; Gordon et al., 2011). It is recognised by firms more advanced in sustainability transitions, that beyond a certain point, their business model cannot advance further towards 
sustainability without 'taking customers with them'. Change can happen behind the scenes (i.e. marketing sustainably - one of the arms of sustainable marketing) (Martin \& Schouten, 2012), but attempting to change the back-end side of the business model without transforming customer ideas of value would likely be myopic and fail (Ottman, Stafford \& Hartmann, 2006, Lim, 2016). Therefore, it is argued that the sustainable marketing concept requires alignment with a paradigm which makes explicitly clear marketing's societal leadership role, otherwise it can never be truly successful in this pursuit. In this context it also becomes vital that managerial approaches to sustainable marketing make clear what approach to leadership is taken, as some are incompatible. For example, in a traditional pathgoal orientated interpretation (House, 1996), a clearly defined goal of the nature of a system that could deliver sustainable wellbeing would be required. However, although a suite of universal needs may be objectively conceived (Max-Neef, 1991), achievement of wellbeing by connecting those needs with particular modes of consumption and economic goods (at a particular space and time), is co-created through the incremental adjustments to subjective symbolic meaning associations of users and lifestyle groups. Any meaning adjustment must start from the landscape that currently exists and evolves over time - the end cannot be known. It is not possible to define the landscape of consumption and production that will optimally meet the goal of sustainable wellbeing within 50 or even 5 years' time either from a company, stakeholder or sustainability perspective. A company devising a specific system of consumption and production and driving people towards it could be seen as the equivalent of selling an outcome rather than 
marketing a path, and therefore would paradigmatically represent 'make-and-sell for sustainable wellbeing' - a myopic approach. Therefore, how marketing perceives its relationship with customers and other stakeholders on the journey to sustainable wellbeing, in other words the type of leadership it engages in, is as significant as assuming its leadership role in the first place. This connects directly to the second aspect of the emerging theory of the consumer - that of the cocreation imperative.

\section{The relational mechanism of co-creation}

Payne, Storbacka and Frow (2008, p.84) note that marketing is gaining credence as "a facilitator and 'structurer' of the mutual creation and enjoyment of value". This view of marketing, as enabler of co-created value between the firm and stakeholders, is one that has gained much ground (Peñaloza \& Venkatesh, 2006; Grönroos \& Voima, 2012). A large body of research focused on co-creation now exists. The increased attention to value co-creation can be seen as due in large part to the service-dominant logic (S-D Logic) of marketing put forward by Vargo and Lusch (2004) (Payne, Storbacka \& Frow 2008). The proposition is that all value is service and products are merely carriers of value. As such, one of S-D Logic's foundational propositions is that "The customer is always a co-creator of value: There is no value until an offering is used - consumer experience and perception are essential to value determination" (Vargo \& Lusch, 2006 p.17). Through this co-creative, service-based lens, value is not assessed at a particular point in time, but experienced and moulded over time, with resources "'becoming', 
not 'being'” (Pels, Möller, \& Saren, 2009, p.328). Value therefore moves from the tangible, objective and static, to the intangible, subjective and movable. In this context, experiential marketing has its underpinnings (Prahalad \& Ramaswamy, 2004) and the rise of relationship marketing takes on greater meaning beyond the capture of 'life-time exchange value' (Grönroos, 1994, 1997, 2000; McAlexander, Schouten \& Koening et al., 2002).

Hence co-creation could be viewed as aligned to the guide-and-co-create paradigm. First, it is aligned to a servitisation business model agenda (services not products as the source of value) - this is a frequently cited sustainability solution (Vendrell-Herrero, Parry, Bustinza, \& O'Regan, 2014). Second, related to this first point, co-creation implicitly aligns with postmodern thinking and Consumer Culture Theory (CCT), regarding the role of symbolic meaning and how meaning it is created and transmitted - critical to the guide-and-co-create paradigm (Berger,1972; Douglas \& Isherwood, 1979; Brown, 1993; Elliott \& Wattanasuwan, 1998). Reference to the social construction and cultural context in which value is created, has, in general, been lacking from within the S-D Logic discourse (Edvardsson, Tronvoll \& Gruber, 2010), although this has notably tackled by some authors who make clear the CCT foundation of the SD logic propositions (Arnould, 2007). 
Co-creation is therefore more than an instrument in a company or marketers' tool kit, but core to the emerging, sustainability aligned, guide-and-co-create paradigm. To be truly valuable, co-creation must be therefore be understood as a new way of viewing the relationship between a business and its stakeholders and as the way in which companies might keep their business model design continually relevant. This would be true if the demands of sustainability did not exist. However, in the context of building sustainable businesses, there is an urgent imperative for marketing to transform current symbolic connections between universal needs, modes of consuming and economic offerings. It is therefore not surprising that some have argued that co-creation and sustainable marketing are "intertwined" (Varey, 2010, p.120), and in this vein, the notion that sustainable business can be achieved without deep co-creative partnerships that incrementally create the asyet-unknown patterns of consumption, is unrealistic.

Despite the significance of co-creation to the guide-and-co-create paradigm of marketing, it is still limited in its ability to drive sustainable marketing because generally within co-creation literature, value is not anchored to any common understanding of wellbeing but has implied subjectivity. As outlined previously, this poses a limitation when addressing issues of sustainability, however it is necessary for alignment with neo-classical assumptions of consumer behaviour.

Temporal and spatial shift 
As indicated from the analysis above, the guide-and-co-create paradigm includes a fundamental shift in the temporal and spatial decision-making frame. The shift to a consideration of long-term wellbeing is core to the emerging theory of the firm, which is strongly influenced by sustainability evidence and thinking. This includes foundational reference to the intergenerational. However, although more long-term in focus, the emerging paradigm as presented above is less about sacrificing the short-term for the long-term, but rather reconciling them though systemic thinking that focuses on transition of the symbolic resource/long-term wellbeing relationship so that future states optimise the wellbeing return on resources. This reflects a fundamental change in perspective from narrow, fragmented, linear and often reactionary to broad, integrated, and systemic, with systems thinking enabling some level of planning and analysis within an otherwise seemingly hyper-chaotic 'VUCA' system (Volatile, Uncertain, Chaotic and Ambigious). Mirroring this shift within marketing, RA Theory (Hunt, 1997) and S-D Logic (Vargo \& Lusch, 2004), draw from a pluralistic range of economic schools of thought and have helped to broaden the temporal scale of firms and marketing. Here, value is situated in a wide and dynamic system - serving to confront some of the deeply held assumptions of the make-and-sell and sense-and-respond paradigms. Table II indicates the characteristics and key differences between the three marketing paradigms. 
Table II Comparison of the Make-and-Sell, Sense-and-Respond and Guide-andCo-Create Paradigms of Marketing

\begin{tabular}{|c|c|c|c|c|}
\hline \multicolumn{2}{|c|}{ Marketing paradigm: } & Make-and-Sell & Sense-and-Respond & Guide-and-Co-create \\
\hline \multicolumn{2}{|c|}{ Theory of the firm: } & $\begin{array}{l}\text { Purpose: Profit } \\
\text { maximisation for } \\
\text { shareholders. } \\
\text { Value: via cost of } \\
\text { production } \\
\text { Focus: Internal } \\
\text { Dominant } \\
\text { economic } \\
\text { theory: Classical }\end{array}$ & $\begin{array}{l}\text { Purpose: Profit } \\
\text { maximisation for } \\
\text { shareholders. } \\
\text { Value: via consumer } \\
\text { preference } \\
\text { Focus: External } \\
\text { Dominant economic } \\
\text { theory: Neo-classical }\end{array}$ & $\begin{array}{l}\text { Purpose: Societal } \\
\text { wellbeing } \\
\text { maximisation in the } \\
\text { long-term. } \\
\text { Value: via transition- } \\
\text { focused relationships } \\
\text { with stakeholders } \\
\text { Focus: Systemic } \\
\text { Dominant economic } \\
\text { theory: Ecological } \\
\text { economics - } \\
\text { heterodox approach }\end{array}$ \\
\hline \multirow{4}{*}{$\begin{array}{l}\text { Paradigmatic } \\
\text { aspect: }\end{array}$} & $\begin{array}{l}\text { 1. Approach } \\
\text { to wellbeing }\end{array}$ & $\begin{array}{l}\text { Wellbeing is not } \\
\text { the concern of } \\
\text { economics. } \\
\text { Welfare is } \\
\text { considered } \\
\text { through } \\
\text { recognition of } \\
\text { some intervention } \\
\text { to reduce } \\
\text { externalities }\end{array}$ & $\begin{array}{l}\text { Utility is a proxy for } \\
\text { wellbeing which was } \\
\text { determined by rational } \\
\text { consumers as } \\
\text { responded to by firms }\end{array}$ & $\begin{array}{l}\text { Achievement of } \\
\text { tangible improvements } \\
\text { in long-term societal } \\
\text { wellbeing is the } \\
\text { primary purpose of the } \\
\text { firm }\end{array}$ \\
\hline & $\begin{array}{l}\text { 2. Theory of } \\
\text { the } \\
\text { consumer }\end{array}$ & $\begin{array}{l}\text { Humans can be } \\
\text { selfish but this is } \\
\text { held in check by } \\
\text { an inherent desire } \\
\text { for self-respect } \\
\text { and respect from } \\
\text { others. Behaviour } \\
\text { must be } \\
\text { understood in a } \\
\text { social context }\end{array}$ & $\begin{array}{l}\text { Humans are self- } \\
\text { interested rational } \\
\text { beings, or bounded- } \\
\text { rational decision } \\
\text { makers who, with the } \\
\text { right information, can } \\
\text { maximise their welfare } \\
\text { through decisions they } \\
\text { make from alternatives } \\
\text { offered in the } \\
\text { marketplace }\end{array}$ & $\begin{array}{c}\text { Dialectic relationships } \\
\text { exist between all } \\
\text { system levels which } \\
\text { shape humans' } \\
\text { identities, values and } \\
\text { practices. Systems of } \\
\text { symbolic meaning } \\
\text { create and reinforce } \\
\text { connections between } \\
\text { wellbeing and } \\
\text { consumption } \\
\end{array}$ \\
\hline & $\begin{array}{l}\text { 3. Dominant } \\
\text { relationship } \\
\text { focus }\end{array}$ & $\begin{array}{l}\text { Internal } \\
\text { (sales) }\end{array}$ & $\begin{array}{l}\text { External } \\
\text { (response) }\end{array}$ & $\begin{array}{l}\text { Systemic } \\
\text { (co-creation) }\end{array}$ \\
\hline & $\begin{array}{l}\text { 4. Dominant } \\
\text { temporal } \\
\text { outlook }\end{array}$ & \multicolumn{2}{|c|}{$\begin{array}{l}\text { Narrow (firm and market system), } \\
\text { fragmented, linear, short-term }\end{array}$} & $\begin{array}{l}\text { Broad (planetary and } \\
\text { future), integrated, } \\
\text { systemic, long-term }\end{array}$ \\
\hline
\end{tabular}


In summary, the emerging 'guide-and-co-create' theory of the firm suggests that a successful business is one that profitably delivers on long-term societal wellbeing outcomes. This is aligned with definitions of sustainability. Within this paradigm, creating and sustaining a successful business requires marketers to guide customers, other stakeholders and the firm in concert towards this goal of greater wellbeing. Marketers are at the heart of creating and adapting business models to transition towards this goal, and their conscious and unconscious action leads society. Within this paradigm, marketing would need to be recognised for its leadership role both inside and outside of the organisation, for organisational success within this paradigm to be realised.

At the same time as marketing must take an active leadership role, marketers cannot know what delivery of sustainable wellbeing looks like or how to get there, as this can only be co-created through transition of the relationships between marketable offerings and underlying needs. To do this requires walking hand-inhand towards that end point with stakeholders - through co-creation. Sustainable marketing leadership without co-creation would be a form of well-meaning green marketing myopia (Ottman et al., 2006), where a best-guess vision would be 'sold' from a distance. On the other hand, co-creation without leadership is akin to a more advanced form of sense-and-respond with no clear long-term wellbeing outcome in mind. 
The emerging guide-and-co-create paradigm is therefore based on a theory of the consumer (and society) which is aligned with the core objectives and demands of sustainability, as well as being based on a theory of the consumer that more accurately reflects what is known about psycho-socio-cultural dynamics. Marketing management practice which is generally aligned with this paradigm is already well developed, such as relationship marketing, co-creation and services marketing. However, reflecting the managerial approach to sustainable marketing, what is often still missing in these theories is explicit reference to the underlying theory of the firm and theory of the consumer that work in this area draws on.

\section{Conclusions: Towards 'guide-and-co-create' principles of sustainable marketing and implications for research and practice}

Many recognise the critical role of business in delivering sustainability, and marketing as central to that endeavour through its critical connection with stakeholders. Sustainable marketing therefore has an important task in helping marketers and managers deliver new ways of translating natural resources into high levels of wellbeing for all. Concerted effort to develop sustainable marketing management approaches is required to support this, however currently these are lacking in number. Additionally, the call for an underlying paradigm shift and what precisely this is going from, and to, is not crystallised clearly enough to spur engagement. As a result, either the opportunity for change is lost, or worse, managerial approaches to sustainable marketing can advertently, or inadvertently, reproduce the incompatible paradigmatic assumptions about the reason for the 
firm's existence, the role of marketing within it, the relationship between the firm and stakeholders, and the dominant temporal timescales of decision making. In this context, this paper has characterised three key paradigms of marketing, which draw from three economic theories of the firm and identifies how their assumptions are compatible or incompatible with the goal of sustainability - long term wellbeing for all.

The time for exposing these paradigmatic issues more boldly appears to have arrived. The economic theory of the firm appears to be in the midst of a profound paradigmatic shift, evidenced by a range of factors including a small but dramatically increasing number of private sector businesses who are attempting to move away from profit maximisation for shareholders as the core reason for existence and instead are situating societal wellbeing as their overarching frame for their organisational purpose. Shifts in managerial and interdisciplinary literature indicate the same trend (e.g. Bartlett \& Ghoshal, 1994; Ellsworth, 2012; Sisodia et al. 2003). This changing context provides an opportunity, and perhaps requirement, for sustainable marketing management to begin to frame itself more concertedly within this emerging paradigm, rather than preceding logics. By framing sustainability as being about wellbeing, the lines between sustainable marketing and the concept of purpose-driven marketing dissolve.

However, it is not just an opportunity but it could be argued that these macro level paradigmatic changes are vital for genuinely sustainable marketing to emerge. For 
example, Latino countries who score high on the New Environmental Paradigm and transcendent values (Schultz and Zelenzny, 1999) or Germany which is known to have a longer-time planning horizon, would require a cultural and structural environment (macro and micro) that supports marketing that is aligned with the guide-and-co-create paradigm. Countries where prosumption (Humphreys \& Grayson, 2008) and consumer social responsibility (CnSR) (Caruana, \& Chatzidakis, 2014) are developed, would expect to find shifts to guide-and-cocreate easier. Whereas for countries such as the US, it would be expected that this paradigmatic transition, borne out by a shift in marketing management practices, would be more challenging.

If marketing managers and their firms are to be able to embark on a journey towards sustainability, they need to be aware of their own paradigmatic tendencies and those of their stakeholders at macro and micro levels. Frameworks of sustainable marketing therefore need to highlight explicitly what tendencies might exist and where these are unhelpful to driving sustainable marketing. The three paradigms summarised in this paper present very different contexts for marketers as summarised in Table II. Make-and-sell and sense-and-respond do not provide reasonable underpinnings for sustainable marketing, for a range of reasons as presented. Guide-and-co-create provides a firmer basis for sustainable marketing management to advance. 
There are key aspects of this new paradigm that have been highlighted as significant, and these form six principles for a sustainable marketing maturity framework. The first four relate directly to the numbered guide-and-co-create paradigmatic aspects in Table II. The extent to which an organisation can demonstrate their marketing management adheres to these principles, the more likely they are to be carrying out 'sustainable marketing'.

First is the emerging firm-level focus on creating sustainable (long-term) wellbeing. This translates into marketing having a primary focus on serving wellbeing (profitably) via a focus on the real needs of stakeholders. Although it relies on the strategic organisational level, it will be manifested in marketing practice. Hence, Principle 1 (guide-and-co-create aspect 1): A marketing managers over-riding purpose is to serve the long-term wellbeing of its target groups (profitably), and this is achieved through serving the long-term wellbeing of stakeholders that enable the purpose.

Second, a postmodern, constructivist (CCT) theory of behaviour points to the critical societal leadership role of marketers and marketing - which must be acknowledged if it is to be harnessed and inadvertent negative wellbeing impacts avoided. Hence, Principle 2 (guide-and-co-create aspect 2): Marketing managers recognise the power and responsibility of their societal leadership role and make their daily decisions with this in mind. 
Third, although marketing leads, at the same time the means by which resources fulfil wellbeing is negotiated through the dynamic landscape of symbolic associations. Creating the sustainable consumption practices of the future requires a process of transition from the current landscape of meaning, to a future one that is, as yet, unknown. Hence co-creation is the core means by which marketing innovation can be appropriately produced, otherwise it is likely to be myopic and ineffective at providing optimised wellbeing within resource constraints. This also has important implications for the role of relationship marketing as the means to create deeper and more meaningful relationships with customers, which is core to success. Hence, Principle 3 (guide-and-co-create aspect 3): Marketing managers can best transition with their stakeholders towards long-term wellbeing through the principles of co-creation. They recognise that nurturing long-term deep relationships is the basis of effective co-creation and core to long-term organisational success.

Fourth, that the temporal and spatial context for the firm, and therefore marketing, is shifting from near-term, narrow, fragmented and linear to long-term, broad, integrated and systemic, requiring new ways of thinking about marketing's core approaches to management and measurement. Hence, Principle 4 (guide-and-cocreate aspect 4): Marketing managers demonstrate long-term, broad systemic thinking in their daily decisions. 
The paper has indicated two further aspects. First that new metrics are required, drawing on the burgeoning literature of social value and environmental indicators, if businesses are to be able to effectively measure the growth of wellbeing for their core service group(s). Hence, Principle 5: Marketing managers work internally and externally to co-create and report on the most appropriate indicators for long-term wellbeing.

Finally, if marketing's leadership role in transitioning business and society in concert to sustainability is to be realised through the above principles, it must be seen as central to business strategy and its implementation. This again relies on the strategic organisational level recognising that and that marketers are central to their long-term relevance. Principle 6: marketing managers work to make clear marketing's central role in developing and sustaining sustainable business models.

By implementing and reporting on these six principles, marketers can be held to account by each other and their organisation for how sustainable their management practices are. In turn, those organisations that claim to be 'sustainable' can be held to account by stakeholders: if they are not practicing genuinely sustainable marketing then how can they claim to be sustainable?

As well as contributing to the need to bridge the critical - managerial divide within the sustainable marketing field, this paper has also emphasised the need for research which considers the extent to which different paradigms exist within 
particular firms and sectors, and in multi-level and multi-actor contexts, and further, what might support its emergence.

\section{References}

Aitken, R., Ballantyne, D., Osborne, P. \& Williams, J. (2006). 'Introduction to the Special Issue on the Service-Dominant Logic of Marketing: Insights from The Otago Forum'. Marketing Theory, 6, 275.

Alderson, W., \& Cox, R. (1948). Towards a theory of marketing. Journal of Marketing, 13, 137-152.

Anderson, P. (1982). Marketing, Strategic Planning and the Theory of the Firm. Journal of Marketing, 46, 15-26.

Andreasen, A. R. (1994). Social marketing: Its definition and domain. Journal of public policy \& marketing, 108-114.

Antonio, R. J. (2015). Is Prosumer Capitalism on the Rise? The Sociological Quarterly, 56, 472-483. 
Armitage, E., C. Béné, A.T. Charles, D. Johnson \& E.H. Allison (2012). 'The Interplay of Well-being and Resilience in Applying a Social-Ecological Perspective'. Ecology and Society, 17, 4-15.

Arndt, J. (1981). The political economy of marketing systems: Reviving the institutional approach. Journal of Macromarketing, 1, 36-47.

Arnould, E. J., \& Thompson, C. J. (2005). Consumer culture theory (CCT):

Twenty years of research. Journal of consumer research, 31, 868-882.

Arnould, E.J. (2007), Service-Dominant Logic and Consumer Culture Theory: Natural Allies in an Emerging Paradigm, in Russell W. Belk, John F.

Sherry (ed.) Consumer Culture Theory (Research in Consumer Behavior, Volume 11) Emerald Group Publishing Limited, pp.57 - 76

Bartels, R. (1976). The History of Marketing Thought, 2nd Ed.,Grid OH: Columbus.

Bartlett, C.A. \& Ghoshal, S (1994), "Changing the role of top management: Beyond strategy to purpose," Harvard Business Review, 72 (6), 79-88. 
Baudrillard, J. (1998). The consumer society: Myths and structures. London:

Sage Publications Ltd.

Baumann, Z. (1998). Work, Consumerism and the New Poor. Milton Keynes: Open University Press.

Beck, U. (1992). Risk society: towards a new modernity. London: Sage Publications Ltd.

Belz, F., \& Peattie, K. (2009). Sustainability marketing: A global perspective. Wiley: NJ.

Berger, J. (1972). Ways of Seeing. UK: Penguin.

Blueprint for Better Business (2017) A purpose that serves society. Available at: http://www.blueprintforbusiness.org/purpose/ Retrieved: 17 January 2017.

Blumer, H. (1969). Symbolic Interactionism; Perspective and Method. NJ: Englewood Cliffs.

Bourdieu, P. (1977). Outline of a Theory of Practice. London: Cambridge University Press. 
Bradley, S.P. \& Nolan, R.L., ed. (1998). Sense \& respond: capturing value in the network era. MA: Harvard Business Press.

Brand-Correa, L. I., \& Steinberger, J. K. (2017). A Framework for Decoupling Human Need Satisfaction From Energy Use. Ecological Economics, 141, 43-52.

Braun, V. \& Clarke, V. (2013). Successful qualitative research: A practical guide for beginners. London: Sage Publications Ltd.

Brown, S. (1993). Postmodern Marketing? European Journal of Marketing, 27, 19-34.

Brownlie, D. \& Saren, M. (1992). The four Ps of the marketing concept: prescriptive, polemical, permanent and problematical. European Journal of Marketing, 26, 34-47.

Carrigan, M. and de Pelsmacker, P. (2009) 'Will Ethical Consumers Sustain their Values in the Global Credit Crunch?' International Marketing Review 26, 674-87

Carson, D., Gilmore, A., Perry, C. \& Gronhaug, K. (2001). Qualitative Marketing Research. London: Sage Publication Ltd. 
Caruana, R., \& Chatzidakis, A. (2014). Consumer Social Responsibility (CnSR): Toward a Multi-Level, Multi-Agent Conceptualization of the" Other CSR". Journal of Business Ethics, 121(4), 577.

Cavagnaro, E., \& Curiel, G. (2012). The three levels of sustainability. Greenleaf Publishing.

Charter, M. (1992). Greener marketing: A responsible approach to business. UK: Greenleaf Publishing.

Csikszentmihalyi, M. \& Rochberg-Halton, E. (1981). The Meaning of Things: Domestic Symbols and the Self. Cambridge: Cambridge University Press.

Clark, J. B. (1907). Essentials of economic theory, as applied to modern problems of industry and public policy. New York NY: The Macmillan Company.

Coddington, W. (1993). Environmental Marketing New York. In McGraw-Hill, M.J. Polonsky, \& A.T.Mintu-Wimsatt (Eds.) Environmental Marketing: Strategies, Practice, Theory and Research. New York NY: Haworth Press.

Costanza, R., Alperovitz, G., Daly, H., Farley, J., Franco, C., Jackson, T., Kubiszewski, I., Schor, J. and Victor, P. (2013). Building a Sustainable and Desirable Economy-in-Society-in-Nature. State of the World, 126-142. 
Crompton, T., Alexander, J. and Shrubsole G. (2011). Think of me as evil. UK: World Wildlife Fund (WWF).

Crompton,T. and Kasser, T. (2009). Meeting Environmental Challenges: The Role of Human Identity. UK: World Wildlife Fund (WWF).

Christensen, P. P. (1989). Historical roots for ecological economics-biophysical versus allocative approaches. Ecological economics, 1, 17-36.

Daly, H. E. (1971). Essays toward a steady-state economy. San Francisco CA: W.H. Freeman and Company.

Deci, E. L., \& Ryan, R. M. (2008). Hedonia, eudaimonia, and well-being: An introduction. Journal of happiness studies, 9, 1-11.

Domagalski, T. A., \& Kasser, T. (2004). The High Price of Materialism. The Academy of Management Review, 29, 135.

Douglas, M. \& Isherwood, B.C. (1979.) The World of Goods. New York NY: Basic Books. 
Dunlap, R. E., \& LIERE, K. D. (1984). Commitment to the dominant social paradigm and concern for environmental quality. Social Science Quarterly, 65(4), 1013.

Eatwell, J. (1987). Walras's Theory of Capital. London: Macmillan.

Edvardsson, B., Tronvoll, B., \& Gruber, T. (2010). Expanding understanding of service exchange and value co-creation: A social construction approach. Journal of the Academy of Marketing Science, 39, 327-339.

Elliott, G. R. (1990). The Marketing Concept - Necessary, but Sufficient? An Environmental View. European Journal of Marketing, 24, 23-30.

Elliott, R. \& Wattanasuwan K. (1998). Brands as symbolic resources for the construction of identity. International Journal of Advertising 17, 131-144.

Ellsworth, R. R. (2002). Leading with Purpose: The New Corporate Realities. USA: Stanford University Press

Emerson, J. (2003). The blended value proposition: Integrating social and financial returns. California Management Review, 45, 35-51. 
Featherstone, M. (1991). Consumer culture and postmodernism. London: Sage Publications Ltd.

Feyerabend, P.K. (1970). Consolations for the specialist. In I. Lakatos \& A. Musgrave (Eds.), Criticism and the Growth of Knowledge, (pp. 197-230). Cambridge: Cambridge University Press.

Firat, A.F., Dholakia, N. \& Venkatesh, A. (1995). Marketing in a postmodernworld. European Journal of Marketing, 29, 40-56.

Fisk, G. (1974). Marketing and the ecological crisis. London: Harper and Row.

Fisk, G. (2001) 'Reflections of George Fisk: Honorary Chair of the 2001 Macromarketing Conference', Journal of Macromarketing, 21, 121-2.

Freeman, R. E. (1984). Strategic Management: A Stakeholder Approach. Englewood Cliffs, NJ: Prentice-Hall.

Fuller, D.A. (1999). Sustainable Marketing - Managerial-Ecological Issues. USA: Sage Publications Ltd. 
Fuller, D. A., \& Butler, D. D. (2014). Eco-Marketing: A Waste Management Perspective. Proceedings of the 1994 Academy of Marketing Science (AMS) Annual Conference Developments in Marketing Science,331-331.

Giddings, B., Hopwood, B., \& O'brien, G. (2002). Environment, economy and society: fitting them together into sustainable development. Sustainable development, 10(4), 187-196.

Goodland, R. \& Ledec, G. (1987). Neoclassical economics and principles of sustainable development. Ecological Modelling, 38, 19-46.

Gordon, R., Carrigan, M. \& Hastings, G. (2011). 'A Framework for Sustainable Marketing', Marketing Theory, 11, 143-63.

Gray, B., Matear, S., Boshoff, C., \& Matheson, P. (1998). Developing a better measure of market orientation. European Journal of Marketing, 32, 884-903.

Grönroos, C. (1994). From Marketing Mix to Relationship Marketing. Management Decision,32, 4-20.

Grönroos, C. (1997). Value-driven relational marketing: From products to resources and competencies. Journal of Marketing Management, 13, 407-419. 
Grönroos, C. (2007). In Search of a New Logic for Marketing: Foundations of Contemporary Theory. John Wiley \& Sons: Chichester.

Grönroos, C., \& Voima, P. (2012). Critical service logic: Making sense of value creation and co-creation. Journal of the Academy of Marketing Science, 41, 133150.

Gummesson, E. (1991). Marketing-orientation revisited: the crucial role of the part-time marketer. European Journal of Marketing, 25, 60-75.

Gummesson, E. (2002). Practical value of adequate marketing management theory. European Journal of Marketing,36, 325-349.

Haeckel, S. H. (1999). Adaptive Enterprise: Creating and Leading Sense-andRespond Organizations. Harvard MA: Harvard Business School Press.

Haeckel, S. (2010). The Post Industrial Manager. Marketing Management, Fall 2010.

Hart, S. L. (1995). A Natural-Resource-Based View of the Firm. The Academy of Management Review, 20, 986.

Hayes, R. H. \& Abernathy W. J. (1980). Managing our way to economic decline. Harvard Business Review, 58, 67-77. 
Henion, K. E. \& Kinnear, T. C. (1976). Ecological Marketing, USA: American Marketing Association

Hickman, L. A. (2007). Pragmatism as post-postmodernism: Lessons from John Dewey, Vol. 21. USA: Fordham University Press.

Hirsch, P. M. \& Levin, D. Z. (1999). Umbrella advocates versus validity police: A life-cycle model. Organisation Science, 10, 199-212.

Ho, H. V. (2010). Enlightened Shareholder Value': Corporate Governance Beyond the Shareholder-Stakeholder Divide. The Journal of Corporation Law, 36, 60.

Hobson, K. (2004). Sustainable consumption in the United Kingdom: the 'responsible' consumer and government at 'arm's length. The Journal of Environment and Development, 13, 121-139.

Hollensbe, E., Wookey, C., Hickey, L., George, G., \& Nichols, C. V. (2014). Organizations with purpose. Academy of Management Journal, 57, 1227-1234.

House, R. J. (1996). Path-goal theory of leadership: Lessons, legacy, and a reformulated theory. Leadership Quarterly, 7. 
Humphreys, A., \& Grayson, K. (2008). The intersecting roles of consumer and producer: A critical perspective on co-production, co-creation and prosumption. Sociology Compass, 2(3), 963-980.

Hunt, S. D. (1997). Resource-advantage theory and the wealth of nations:

Developing the socio-economic research tradition. The Journal of SocioEconomics, 26, 335-357.

Hunt, S. D. (2011). Sustainable marketing, equity, and economic growth: A resource-advantage, economic freedom approach. Journal of the Academy of Marketing Science, 39, 7-20.

Hunt, S.D. (2012). Toward the Institutionalization of Macromarketing: Sustainable Enterprise, Sustainable Marketing, Sustainable Development, and the Sustainable Society. Journal of Macromarketing, 32, 404-411.

Hurth, V. (2010). Creating sustainable identities: The significance of the financially affluent self. Sustainable Development, 18,123-134.

Hutt, W. H. (1940). The Concept of Consumer Sovereignty. Economic Journal, $50,66-77$.

IUCN. (2006). Report of the IUCN Renowned Thinkers Meeting, 29-31 January. 
Jackson, T and Marks, N. (1999). Consumption, sustainable welfare and human needs - with reference to UK expenditure patterns between 1954 and 1994. Ecological Economics, 28, 421-441.

Jackson, T. (2005). Motivating sustainable consumption. Sustainable Development Research Network, 29, 30.

Jameson, F. (1991). Postmodernism, or, The cultural logic of late capitalism. Durham: Duke University Press.

Jaworski, B. J. \& Kohli, A. K. (1993). Market Orientation: Antecedents and Consequences. Journal of Marketing, 57, 53.

Jayachandran , S., Hewitt, K. \& Kaufman, P. (2004). Customer Response Capability in a Sense-and-Respond Era: The Role of Customer Knowledge Process. Journal of the Academy of Marketing Science, 32, 219-233.

Kahneman, D., Slovic, P. \& Tversky, A. (1982). Judgment under uncertainty: Heuristics and biases. Cambridge: Cambridge University Press.

Kay, J. (2012). The Kay Review of UK Equity Markets and Long-Term Decision Making: interim report. UK, UK Government. 
Keith, R. J. (1960). The Marketing Revolution. Journal of Marketing, 24, 35.

Kilbourne, W. E. (2004). Sustainable communication and the dominant social paradigm: Can they be integrated? Marketing Theory, 4, 187-208.

Kilbourne, W., McDonagh, P., \& Prothero, A. (1997). Sustainable consumption and the quality of life: A macromarketing challenge to the dominant social paradigm. Journal of macromarketing, 17, 4-24.

Kotler, P. and Levy, S.J. (1969). Broadening the Concept of Marketing. Journal of Marketing, 33,10-15.

Kotler, P., \& Zaltman, G. (1971). Social marketing: an approach to planned social change. The Journal of Marketing, 3-12.

Kotler, P., Kartajaya, H., \& Setiawan, I. (2010). Marketing 3.0: From products to customers to the human spirit. John Wiley \& Sons.

Kotler, P. (2011). Reinventing Marketing to Manage the Environmental Imperative. Journal of Marketing, 75, 132-135. 
Kuhn, T.S. (1970). The Structure of Scientific Revolutions 2nd Ed. Chicago IL. University of Chicago Press.

Kumar, V. (2015). Evolution of marketing as a discipline: What has happened and what to look out for. Journal of Marketing, 79, 1-9.

Laczniak, G. R., \& Murphy, P. E. (2006). Normative perspectives for ethical and socially responsible marketing. Journal of Macromarketing, 26, 154-177.

Laczniak, G. R., \& Murphy, P. E. (1985). Marketing Ethics Guidelines for Managers. USA: Lexington Books

Lakatos, I. (1970). Falsification and the methodology of scientific research programmes. In I. Lakatos, \& A. Musgrave (Eds.), Criticism and the Growth of Knowledge. Cambridge: Cambridge University Press.

LaLonde, B.J. (1963). Evolution of the Marketing Concept. The frontiers of marketing Thought and Science. American Marketing Association Proceedings, December, 341.

Laloux, F. (2014). Reinventing organizations. UK, Nelson Parker 
Laudan, L. (1977). Progress and its Problems: Toward a Theory of Scientific Growth. California CA: University of California Press.

Lee, D. J., and Sirgy, M.J. 2004. Quality-of-life marketing: Proposed antecedents and consequences. Journal of Macromarketing, 24, 44-58.

Levitt, T. (1960). Marketing Myopia. Harvard Business Review, 45-46.

Lim, W. M. (2016). A blueprint for sustainability marketing: Defining its conceptual boundaries for progress. Marketing Theory, 16, 232-249.

Lusch, R. F., \& Laczniak, G. R. (1987). The evolving marketing concept, competitive intensity and organizational performance. Journal of the Academy of Marketing Science, 15, 1-11.

Marshall, A. (1890). Principles of Economics, $1^{\text {st }}$ Ed. London: Macmillan.

Martin, T.R. (1985), "Ethics in marketing: problems and prospects", in Laczniak, G.R. and Murphy, P.E. (Eds), Marketing Ethics: Guidelines for Managers, Lexington Books, Lexington, MA, 1-7.

Martin, D. \& Schouten, J. (2012). Sustainable Marketing. MA: Prentice Hall. 
Max-Neef, M. A. (1991). Human Sale Development- Conception, Application and Further Reflection. New York NY: Apex Press.

Max-Neef, M.A. (1995). Economic growth and quality of life, a threshold hypothesis. Ecological Economics, 15, 115-118.

McAlexander, J. H., Schouten, J. W., and Koening, H. F. (2002) ‘Building Brand Community', Journal of Marketing 66, 38-55.

McDonagh, P. \& Prothero, A. (2014). Sustainability marketing research: Past, present and future. Journal of Marketing Management, 30, 1186-1219.

McFadden, D. (2006). Free Markets and Fettered Consumers †. American Economic Review, 96, 5-29.

McGregor, J. A., \& Pouw, N. R. M. (2016). Towards an Economics of Wellbeing: What would economics look like if it were focused on human wellbeing? Cambridge Journal of Economics.

McManus, P. (1996). Contested terrains: politics, stories and discourses of sustainability. Environmental Politics, 5, 48-73. 
Meadows, D. H. (1998). Indicators and information systems for sustainable development. USA: The Sustainability Institute.

Menon, A. \& Menon, A. (1997). Enviropreneurial marketing strategy: the emergence of corporate environmentalism as market strategy. The Journal of Marketing, 51-67.

Merriam, S. B., \& Merriam, S. B. (1998). Qualitative research and case study applications in education. San Francisco CA: Jossey-Bass.

Mick, D., Pettigrew, S.\& Ozanne, J, (Eds). (2012). Transformative Consumer Research for Personal and Collective Wellbeing. New York NY: Taylor and Francis.

Morgan, N.A. (2012). Marketing and business performance. Journal of the Academy of Marketing Science, 40, 102-119.

Nordhaus, W. D. (2011). Energy: friend or enemy. The New York review of books, 27, 29-31.

Nussbaum, M. C., and A. Sen, (Eds.) (1993). The Quality of Life. Oxford: Clarendon Press. 
Ottman, J. A. (1992). Industry's response to green consumerism. Journal of Business Strategy, 13, 3-7.

Ottman, J. A., Stafford, E.R. \& Hartmann, C.L. (2006). Avoiding green marketing myopia, Environment. Science and Policy for Sustainable Development, 48, 2236.

Oyserman, D. (2009). Identity-based motivation and consumer behavior. Journal of Consumer Psychology, 19, 276-279.

Parrish, B.D. (2010).Sustainability-driven entrepreneurship: Principles of organization design. Journal of Business Venturing, 25, 510-523

Payne, A. F., Storbacka, K. \& Frow, P. (2008). Managing the co-creation of value. Journal of the Academy of Marketing Science,36, 83-96.

Peterson, M. (2012). Envisioning and Developing Sustainable Enterprise: A Macromarketing Approach. Journal of Macromarketing, 32, 393-396.

Peterson, M. (2013). Sustainable Enterprise. A Macromarketing Approach. CA, Sage Publications Inc.

Peattie, K. (1999). Green Marketing. UK: MacDonald and Evans. 
Peattie, K. (2007). 'Sustainable Marketing: Marketing Re-thought, Re-mixed and Re-tooled', in M. Saren, P. Maclaran, C. Goulding, R. Elliott, A. Shankar \& M. Catterall (Eds.). Critical Marketing: Defining the Field, (193-207). London: Butterworth-Heineman.

Peattie, K. \& Peattie, S. (2009). Social marketing: A pathway to consumption reduction? Journal of Business Research, 62, 260-268.

Peattie, S. \& Peattie, K. (2003). Ready to fly solo? Reducing social marketing's dependence on commercial marketing theory. Marketing Theory, 3, 365-385.

Pels, J., Möller, K. \& Saren, M. (2009). Do we really understand business marketing? Getting beyond the RM and BM matrimony. Journal of Business and Industrial Marketing, 24, 322-336.

Peñaloza, L. and Venkatesh, A. (2006). Further evolving the new dominant logic of marketing: from services to the social construction of markets. Marketing Theory, 6, 299-316.

Persky, J. (1993). Retrospectives: Consumer Sovereignty. The Journal of Economic Perspectives, 7, 183-191. 
Pigou, A. C. (2013). The economics of welfare. London: Palgrave Macmillan.

Porritt, J. (2010). Towards a sustainable economy Business leadership \& UK Government policy, University of Cambridge, Next Economy Initiative.

Porter, M. E. \& Kramer, M. R. (2011). Shared value: How to reinvent capitalismand unleash a wave of innovation and growth. Harvard Business Review, 89, 6277.

Prahalad, C. K. \& Bettis, R. A. (1986). The dominant logic: a new linkage between diversity and performance. Strategic Management Journal, 7, 485501.

Prahalad, C. \& Ramaswamy, V. (2004). Co-creation experiences: The next practice in value creation. Journal of Interactive Marketing, 18, 5-14.

Rettie, R., Burchell, K., \& Riley, D. (2012). Normalising green behaviours: A new approach to sustainability marketing. Journal of Marketing Management, 28, 420444.

Roderick, L. (2016) 'Purpose before profit: Why Innocent wants to leave the planet 'a little better than we found it'. Marketing Week, Available at: https://www.marketingweek.com/2016/02/03/purpose-before-profit-why-innocent- 
wants-to-leave-the-planet-a-little-better-than-we-found-it/ Retrieved 17th January 2017.

Ruccio, D.F. \& Amariglio. J. (2015). Postmodern Moments in Modern Economics. NJ: Princetown University Press.

Samuelson, P. A. (1948). Consumption theory in terms of revealed preference. Economica, 15, 243-253.

Saren, M. (2000). Sustainable Marketing: Managerial-Ecological Issues 20001D.A. Fuller. Sustainable Marketing: Managerial-Ecological Issues. USA, Sage Publications Ltd: 1999. European Journal of Marketing, 34(5/6), 747-748.

Say, J.B. (1834). A Treatise on Political Economy, 6th US Ed.

Schaefer, A. \& Crane, A. (2005). Addressing sustainability and consumption. Journal of macromarketing, 25, 76-92.

Schultz, P. W., \& Zelezny, L. (1999). Values as predictors of environmental attitudes: Evidence for consistency across 14 countries. Journal of environmental psychology, 19(3), 255-265. 
Schutte, T.F. \& Wind, Y. (1968). The Marketing Concept Revisited: A Decade Recap of Its Development and Meaning. Wharton School Working Paper, Jan.

Sheth, J, and Parvatiyar, A. (1995). Ecological imperatives and the role of marketing. Environmental marketing: Strategies, practice, theory and research, 3-20.

Shove, E., \& Pantzar, M. (2005). Consumers, producers and practices: understanding the invention and reinvention of Nordic walking. Journal of consumer culture, 5, 43-64.

Sen, A.K. (1977). Rational Fools: A Critique of the Behavioral Foundations of Economic Theory. Philosophy and Public Affairs, 6, 317-344

Simon, H. A. (1982). Models of bounded rationality: Empirically grounded economic reason (Vol. 3). USA: MIT Press.

Sinek, S. (2009). Start with why: How great leaders inspire everyone to take action. UK: Penguin.

Sirgy, M. J., Meadow, H. L. \& Samli, A. C. (1995). Past, present, and future: An overview of quality of life research in marketing. New dimensions in marketing/quality-of-life research, 335-364. 
Sirgy, M. J.\& A. C. Samli, (Eds.). (1995). New dimensions in marketing/quality-oflife research. London: Quorum Books.

Sirgy, J.M., Michalos, A.C., Ferriss, A.L., Easterlin, R.A., Patrick, D. \&Pivot, W. (2006). The quality-of-life (qol) research movement: past, present, and future. Social Indicators Research, 76,343-466.

Sisodia, R., Wolfe, D., \& Sheth, J. N. (2003). Firms of endearment: How worldclass companies profit from passion and purpose. Pearson Prentice Hall.

Smith, A. (1776). An Inquiry into the Nature and Causes of the Wealth of Nations. London: Methuen \& Co. Ltd.

Smith, A. (1790 [2010]). The theory of moral sentiments. Penguin.

Stiglitz, J. E. (2010). Freefall: America, free markets, and the sinking of the world economy. NY: W.W. Norton and Co.

Stockhammer, E. (2004). Financialisation and the slowdown of accumulation. Cambridge Journal of Economics, 28, 719-741. 
Sutherland, R. (2010). We can't run away from the ethical debates in Marketing. Market Leader. January 2010.

UNESA (2012). Back to Our Common Future. May 2012 United Nations Department of Economic and Social Affairs. Available at:

https://sustainabledevelopment.un.org/index.php?page $=v i e w \& n r=624 \& t y p e=400$ \&menu $=35$ Retrieved $5^{\text {th }}$ January 2016

Unilever, 2016. Our Business Model. Available at: https://www.unilever.com/about/who-we-are/our-strategy/ Retrieved $18^{\text {th }}$ May 2016.

Vaish, M.C. (2009). Macroeconomic Theory. $13^{\text {th }}$ Ed. Delhi: Vikas Publishing House.

Van Dam, Y.K. \& Apeldoorn, P.A.C. (1996). Sustainable Marketing, Journal of Macromarketing, Fall, 45-56.

Varadarajan, R. (2010). Strategic marketing and marketing strategy: Domain, definition, fundamental issues and foundational premises. Journal of the Academy of Marketing Science. 38, 119-140.

Varey, R. J. (2011). A sustainable society logic for marketing. Social Business, 1, 69-83. 
Varey, R. J. (2010). Marketing means and ends for a sustainable society: A welfare agenda for transformative change. Journal of Macromarketing, 30, 112126.

Varey, R. J. (2013). Marketing in the flourishing society megatrend. Journal of Macromarketing, 33, 354-368.

Vargo, S. L. \& Lusch, R. F. (2004). Evolving to a New Dominant Logic for Marketing. Journal of Marketing 68, 1-17.

Vargo, S.L. \& Morgan, F.W. (2005). Services in Society and Academic Thought: An Historical Analysis. Journal of Macromarketing, 25, 42-53.

Vargo, S., \& Lusch, R. (2006). Service-dominant logic: What it is, what it is not, what it might be. In R. F. Lusch, \& S. L. Vargo (Eds.), The service dominant logic of marketing: Dialog, debate, and directions (pp. 43-56). New York NY: ME Sharpe..

Vendrell-Herrero, F., Parry, G., Bustinza, O. F.\& O'Regan, N. (2014).

Servitization as a Driver for Organizational Change. Strategic Change, 23, 279285. 
Webster, F.R. (2009). Marketing IS management: The wisdom of Peter Drucker. J of the Acad. Mark. Sci. 37,20-27.

Wheeler, D., Colbert, B. \& Freeman, R. E. (2003). Focusing on value: reconciling corporate social responsibility, sustainability and a stakeholder approach in a network world. Journal of General Management, 28, 1-28.

Wilk, R. (1999). Quality of Life and the Anthropological Perspective. Feminist Economics, 5, 91-93.

Wilk, R. (2002). Consumption, human needs and global environmental change. Global Environmental Change, 12, 5-13.

Wilkie, W. L., \& Moore, E. S. (1999). Marketing's contributions to society. Journal of Marketing, 63, Special Millenium Issue, 198-218.

Wilkie, W. L. \& Moore, E. S. (2012). Expanding our understanding of marketing in society. Journal of the Academy of Marketing Science, 40, 53-73.

Wilkie, W. L., \& Moore, E. S. (2013). A Larger View of Marketing. Marketing and the Common Good: Essays from Notre Dame on Societal Impact, 13.

Wissenburg, M. (1998). Green Liberalism. The free and the green society. 
London: UCL Press. 